\title{
Aa. Vv., Le Théâtre-Historique d'Alexandre Dumas. II. Directeurs, décorateurs, musique, correspondances, censure
}

\section{Lise Sabourin}

\section{(2) OpenEdition Journals}

Édition électronique

URL : http://journals.openedition.org/studifrancesi/6694

DOI : 10.4000/studifrancesi.6694

ISSN : 2427-5856

Éditeur

Rosenberg \& Sellier

\section{Édition imprimée}

Date de publication : 1 septembre 2010

Pagination : 389-390

ISSN : 0039-2944

\section{Référence électronique}

Lise Sabourin, «Aa. Vv., Le Théâtre-Historique d'Alexandre Dumas. II. Directeurs, décorateurs, musique, correspondances, censure », Studi Francesi [En ligne], 161 (LIV | II) | 2010, mis en ligne le 30 novembre 2015, consulté le 11 janvier 2021. URL : http://journals.openedition.org/studifrancesi/6694 ; DOI : https://doi.org/10.4000/studifrancesi.6694

Ce document a été généré automatiquement le 11 janvier 2021.

\section{cc) (†) $\odot$}

Studi Francesi è distribuita con Licenza Creative Commons Attribuzione - Non commerciale - Non opere derivate 4.0 Internazionale. 


\title{
Aa. Vv., Le Théâtre-Historique d'Alexandre Dumas. II. Directeurs, décorateurs, musique, correspondances, censure
}

\author{
Lise Sabourin
}

\section{RÉFÉRENCE}

Le Théâtre-Historique d'Alexandre Dumas. II. Directeurs, décorateurs, musique, correspondances, censure, «Cahiers Alexandre Dumas», n²6, 2009, pp. 222.

Continuant la démarche du $n^{\circ} 25$, ce nouveau «Cahier Alexandre Dumas» nous délivre la liste des directeurs et des décorateurs du Théâtre-Historique (pp.11-17), avant une analyse d'Olivier BARA sur l'importance de cette salle comme «théâtre en musique» (pp. 18-29) et l'annotation par Claude schоре (pp. 31-165, index pp. 166-173) des correspondances reçues et conventions signées de 1846 à 1851. Puis Odile KRAKOVITCH (pp. 174-196) ouvre les dossiers de censure de La Reine Margot, Hamlet, L'École des familles, L'Intrigue et l'amour, Le Mari de la veuve, Le Chevalier de Maison rouge ou les Girondins, Le Comte de Monte-Christo, Le Capitaine Lajonquière qui y furent représentés et Jacqueline RAZGONNIKOFF, par le «petit bout de la lorgnette» (pp.197-206), fournit une sélection thématique des articles du «Coureur des spectacles» consacrés à ce lieu théâtral. Enfin Jean-Claude YON (pp. 207-216) clôt l'enquête ainsi opérée en présentant la «brève histoire d'une reconversion», du Théâtre-Historique au Théâtre-Lyrique. Une précision rectificative du précédent et une bibliographie 2008 viennent achever ce numéro riche de documents fort utiles sur un théâtre «qui a eu la fulgurance aussi bien que la brièveté de l'éclair» (avant-propos, p. 10). 